\title{
A Review of Coupled Hydrologic-Hydraulic Models for Floodplain Assessments in Africa: Opportunities and Challenges for Floodplain Wetland Management
}

\author{
Innocent C. Chomba ${ }^{1, *}$, Kawawa E. Banda ${ }^{1}{ }^{(}$, , Hessel C. Winsemius ${ }^{2}{ }^{\mathbb{D}}$, Machaya J. Chomba ${ }^{3}$, Mulema Mataa $^{1}$, \\ Victoria Ngwenya ${ }^{1}$, Henry M. Sichingabula ${ }^{4}$, Imasiku A. Nyambe ${ }^{1}$ and Bruce Ellender ${ }^{3}$ \\ 1 Integrated Water Resources Management Center, Department of Geology, School of Mines, The University \\ of Zambia, Lusaka 32379, Zambia; kawawa.banda@unza.zm (K.E.B.); 2018270109@student.unza.zm (M.M.); \\ 2018245280@student.unza.zm (V.N.); inyambe@unza.zm (I.A.N.) \\ 2 Faculty of Civil Engineering and Geosciences, Water Resources Delft University of Technology, \\ 5048 Delft, The Netherlands; hessel.winsemius@deltares.nl \\ 3 Worldwide Fund for Nature (WWF) Zambia, Plot 4978, Los Angeles Boulevard, Longacres, \\ Lusaka 50051RW, Zambia; mchomba@wwfzam.org (M.J.C.); bellender@wwfzam.org (B.E.) \\ 4 Department of Geography and Environmental Studies, School of Natural Sciences, The University of Zambia, \\ Lusaka 32379, Zambia; sichingabula@unza.zm \\ * Correspondence: 2018269976@student.unza.zm; Tel.: +260-974-122-595
}

check for updates

Citation: Chomba, I.C.; Banda, K.E.; Winsemius, H.C.; Chomba, M.J.;

Mataa, M.; Ngwenya, V.;

Sichingabula, H.M.; Nyambe, I.A.; Ellender, B. A Review of Coupled Hydrologic-Hydraulic Models for Floodplain Assessments in Africa: Opportunities and Challenges for Floodplain Wetland Management. Hydrology 2021, 8, 44. https:// doi.org/10.3390/hydrology8010044

Received: 21 January 2021

Accepted: 28 February 2021

Published: 11 March 2021

Publisher's Note: MDPI stays neutral with regard to jurisdictional claims in published maps and institutional affiliations.

Copyright: (c) 2021 by the authors. Licensee MDPI, Basel, Switzerland. This article is an open access article distributed under the terms and conditions of the Creative Commons Attribution (CC BY) license (https:/ / creativecommons.org/licenses/by/ $4.0 /)$.
Abstract: Floodplain wetlands are a fundamental part of the African continent's ecosystem and serve as habitat for fish and wildlife species, biodiversity, and micro-organisms that support life. It is generally recognised that wetlands are and remain fragile ecosystems that should be subject to sustainable conservation and management through the use of sustainable tools. In this paper, we propose a synthesis of the state of art concerning coupled hydrologic and hydraulic models for floodplains assessments in Africa. Case studies reviewed in this paper have pointed out the potential of applying coupled hydrologic and hydraulic models and the opportunities present to be used in Africa especially for data scarce and large basin for floodplain assessments through the use of available open access models, coupling frameworks and remotely sensed datasets. To our knowledge this is the first case study review of this kind on this topic. A Hydrological model coupled with Hydraulic Model of the floodplain provides improvements in floodplain model simulations and hence better information for floodplain management. Consequently, this would lead to improved decision-making and planning of adaption and mitigation measures for sound floodplain wetland management plans and programmes especially with the advent of climate change and variability.

Keywords: coupled modelling; hydrologic models; hydraulic models; floodplain; wetland management

\section{Introduction}

According to [1], wetlands often occur as ecotones (transition zones) between dryland and a water body (e.g., along the margins of lakes, ponds, reservoirs, rivers, and streams) or in channels of sluggish or intermittent streams and rivers. Low-lying lands in these locations may be frequently flooded during high-water periods. Many other wetlands however, form in areas not adjacent to a water body. These wetlands are found in isolated depressions on the land where water collects, on hill slopes where springs occur or groundwater seeps to the surface, in low areas with poorly drained soils (with seasonally high-water tables), and in areas where clayey soils, impervious rock, or other restrictions near the surface create a perched water table [2]. Wetlands may also form in other altered landscapes such as mined lands (e.g., abandoned gravel pits). Thus, a wetland can be thought of as a wet land (i.e., land which is wet). However, not all wet land results in a wetland. Because a wetland is found where the land is wet enough (i.e., saturated or flooded) for long enough to be unfavourable to most flora but are favourable to flora 
adapted to anaerobic soil conditions. As soil becomes increasingly wet, the water starts to fill the space between the soil particles. When all the spaces are filled with water the soil is said to be saturated. In areas which are not wetlands, water drains away quickly and the soil does not remain saturated. However, in wetlands the water persists or drains away very slowly and the soil remains saturated or flooded for long periods [2]. These interactions suggest complex hydrologic-hydraulics processes that need to be evaluated to sustain wetlands.

Floodplain wetlands, like any other wetland type, impact on climate, hydrology, geomorphology, and flora (Figure 1). These factors play an important role in determining characteristics of the wetland catchment, such as its physical form, hydrology, water properties, biota and soils [3]. Floodplain wetlands have developed around the globe in different climates, physiographic regions, and hydrologic settings resulting in a wide diversity of types. No floodplain wetlands are exactly the same, for they differ in size, shape, biological characteristics, environmental conditions, and human influences [4]. Depending on the geographic location, floodplains can flood as frequently as multiple times a year (wetter, subtropical climates) or as infrequently as only once every decade or more (drier, desert climates). Floodplains can also flood for varied periods of time. In tropical climates floods may persist for multiple months or entire seasons, while in mid-latitude climates floods last for only a period of days or weeks [5].

A floodplain can also be regarded as a kind of wetland, whereby the land surface adjacent to a stream or river that is formed, in-part, by river processes and floods during discharge events, can flow out of the channel and onto the surrounding land surface. Floodplains are typically characterized by high biological productivity. Aquatic ecosystems productivity is enhanced in many floodplain areas by the continued import and retention of nutrient-rich sediments from headwater regions and lateral sources, increased water supply, and more oxygenated root zones as a result of flowing waters [6]. The flood pulse advantage has long been recognized based on the extent of the annual flood since ancient times. It has been argued that there is a very strong relationship that exists between inundation extent and discharge/water level. This implies that trends in flooding and inundation extent are mirrored in trends of discharge/water level and the reverse holds true [7]. Thus, globally, floodplains may be of greater value to society than any other ecosystem type. This is because of the critical role that interactions between flood-plains and associated streams play in maintaining supplies of clean water. While that role is conceptually simple, the processes which define interactions (i.e., floodplain functions) in aquatic terrestrial ecotones are exceedingly complex [6]. In most rivers, flood-plain inundation occurs when the discharge exceeds the capacity of the channel and flows overbank. However, in some settings, flood waters leave the river via flow paths that laterally connect the river and floodplain and inundate the floodplain prior to filling the channel. Floodplains wetlands occur in nearly all tributary and main-stem river valleys (with the exception of channel heads) and can be found in alluvial and bedrock rivers, though they are most common in alluvial rivers [5]. 

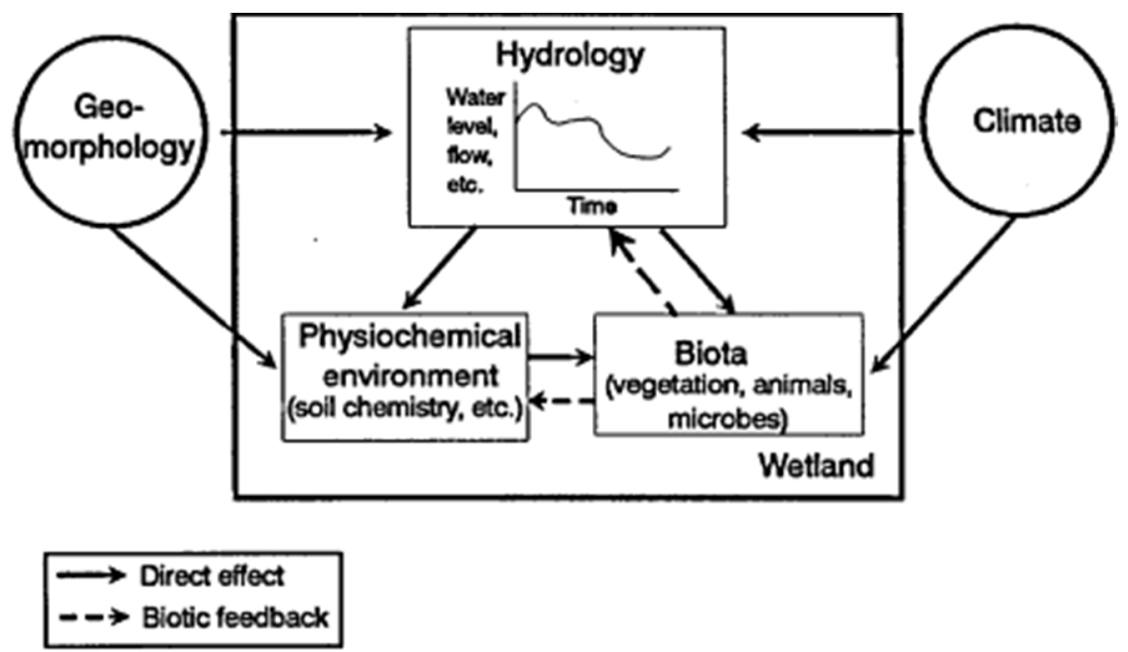

Figure 1. Key characteristics of all wetlands (hydrology, physico-chemical environment and biota), key wetland drivers (geomorphology and climate) and the relationships between them as adapted from National Research Council by Victorian Department of Sustainability and Environment [8].

A key concept in understanding floodplain is that floodplains are as a result of a number of drivers as illustrated in Figure 1. Climate and geomorphology of a landscape do define the hydrology and initial chemistry of river channels. River channel characteristics determine the hydrology, soil characteristics, environment of aquatic flora and fauna, and biogeochemistry of the floodplain. In turn, biogeochemical feedback from floodplains to river channels helps define the environment seen by aquatic flora and fauna. The gradations of those interactions form the basis of the role of floodplains as ecotones and regulators of energy and nutrient exchange. Thus, a strong interdependency exists between aquatic and terrestrial components of riparian ecotones. It is critical to understand this relationship for sustainable management of the floodplain wetlands. Interchange of water between floodplains and rivers is very complex and involves mutualistic influences [6]. For instance, the widely known global phenomenon is that hydrological models for floodplain assessments without the inclusion of floodplain attenuation effects tend to overestimate peak flows. However, a recent study [9] demonstrated that without treating a floodplain wetland as a pseudo reservoir, hydrological models like SWAT actually overestimates base flow rather than peaks flows demonstrating further the complexity of modelling floodplains. Hence, the need to try and understand the feedback exchange processes in assessing floodplains through the use of coupled hydrologic and hydraulic models.

\section{Materials and Methods}

In recent years the demand for an understanding the hydrological and hydrodynamic processes that govern floodplain wetlands is ever increasing, especially with the advent of climate change-variability and its potential impact on hydrological variables such as precipitation, stream flow, soil moisture, groundwater recharge, and evapo-transpiration [10-12]. In the absence of adequate and continuous historical observations for most basins in Africa, advances in remote sensing and computing power and model coupling frameworks, have made models an increasingly attractive solution where spatial understanding of hydrology and hydraulics research of wetlands is required [13]. Thus, research on the hydrological dynamics of basins in Africa can benefit from these advances and coupling of hydrology and hydraulics to allow for physically more integrated assessments and to compensate for their respective shortcomings [14]. Hydrologic models rely on the parameterisation of watershed properties and rainfall patterns and depths to produce a flood hydrograph of discharge at discrete time steps. These models have become widely used in flood forecasting, stream flow prediction, and to quantify effects of climate change, land use impacts or other spatially distributed properties. However, their limited routing methods do have 
some drawbacks in simulating flows in large watersheds. Examples of hydrologic models include the wflow, Hydrologic Engineering Center-Hydrologic Modeling System (HECHMS), the Hydrologic Simulation Program-FORTRAN (HSPF), Soil and Water Assessment Tool (SWAT), and MIKE-SHE [15-17].

On the other hand, hydraulic models are based on the solutions to St. Venant equations to calculate open channel flow. The most commonly used of these models are either onedimensional or two-dimensional. Widely used hydraulic models include Lisflood-FP (1D and 2D models), Water Quality Analysis Simulation Program (WASP), CE-QUALW2, Environmental Fluid Dynamics Code (EFDC), EPDRIV1, Hydrologic Engineering Center-River Analysis System (HEC-RAS), MIKE11 (1-D model), MIKE21 (2-D model), and SOBEK $[18,19]$. Coupling models to share fluxes at each time step as feedback is important in floodplains and should be accounted for. Hence, it is becoming quite common to couple hydrologic and hydraulic models for floodplain simulation [20]. One of the advantages of hydrological modelling that Africa can benefit from, is the free access of hydrological- hydraulic models, such as The Soil and Water Assessment Tool (SWAT) model, wflow, Precipitation Runoff Modeling System (PRMS), Lisflood-FP, The CaMaFlood (Catchment-based Macro-Scale Floodplain) Hydrologic Engineering Center's -River Analysis System (HEC-RAS) in comparison to commercial models are such as Mike II, MIKE SHE [15-17].

Globally, with computation power increasing over the past decade, hydrologichydrodynamic coupling has already been applied in numerous studies [21-23]. For example, by using GLOFRIM, [20] coupled the global hydrologic model PCR-GLOBWB with the hydrodynamic models CaMa-Flood and Lisflood-FP. Results show that replacing the kinematic wave approximation of the hydrologic model with the local inertia equation of CaMa-Flood greatly enhances accuracy of peak discharge simulations as expressed by an increase in the Nash-Sutcliffe efficiency (NSE) from 0.48 to 0.71 . Flood maps obtained with LISFLOOD-FP improved representation of observed flood extent. It was concluded that model coupling can indeed be a viable way forward in more integrated flood simulations. However, results also suggest that the accuracy of coupled models still largely depends on the model forcing [20]. Ref. [21] linked the hydrologic model HSPF with the one-dimensional hydraulic model UNET in order to capture the complicated hydraulics of the Illinois River. They compared the linked model and HSPF alone to see how well the models reproduced historical flows. Their work found a decrease in error of simulated flood peaks as compared to observed peaks and slight increases in efficiency of the coupled model in daily, monthly, and annual flows, though this decreased with increasing time period. These studies show the possible improvements that can be realised through model coupling. Ref. [21] argues that since flooding inundation is driven by hydrologic or river routing and floodplain flow processes and are often simulated by different models, coupling these models may be a viable way to increase the integration of different physical drivers of simulated inundation estimates.

This article provides a case studies synthesis of the current body of knowledge on coupled hydrologic and hydraulic modelling of floodplains in Africa. The goal is to address the opportunities presented by coupled models in the management of floodplain wetland resources on the continent. This goal is particularly urgent in the face of the continuing and dramatic deterioration of wetlands resulting from anthropogenic activities, as well as the projected impact of global climate change on hydrological cycles globally.

\section{Results and Discussion}

\subsection{General Findings}

Coupling hydrological and hydraulic model is the combining of hydrologic and hydraulic models in floodplain modelling. Since floodplain responses highly depend on the inflow coming from other parts of the basin, floodplain inundation models are usually forced with observed upstream discharges or coupled (combined) to hydrologic models, where the hydrologic model is providing the upstream boundary conditions such 
as discharge to the hydraulic model (this can either be done in an offline manner or online manner) [24]. The coupling of the hydrological and hydraulic models is applied in four case studies [24-27]. All these studies were conducted in data scarce basins between 2016 to 2019. In particular, studies [25-27] were based on one directional hydrological and hydraulic coupling, while study [24] applies a two directional coupling of hydrological and hydraulic models. This is an online coupling that allows a two-directional feedback between floodplain hydrodynamics and vertical hydrology, since runoff generation and channel/floodplain dynamics are treated as interdependent processes [24] (Table 1). The other most important finding is the scarcity of studies using coupled models for floodplain assessment in Africa.

Table 1. Results of peer-reviewed case studies that used coupled hydrologic-hydraulic modelling in floodplain studies in Africa.

\begin{tabular}{ccccc}
\hline Reference & $\begin{array}{c}\text { Form of } \\
\text { Coupling }\end{array}$ & $\begin{array}{c}\text { Aim for Application of Coupled } \\
\text { Modelling }\end{array}$ & $\begin{array}{c}\text { Basin } \\
\text { Applied }\end{array}$ & $\begin{array}{c}\text { Coupled } \\
\text { Model }\end{array}$ \\
\hline $\begin{array}{c}\text { Komi et al., } \\
(2017)\end{array}$ & $\begin{array}{c}\text { One-directional } \\
\text { coupling }\end{array}$ & $\begin{array}{c}\text { hydrological modelling; } \\
\text { flood inundation modelling; } \\
\text { LISFLOOD; } \\
\text { LISFLOOD-FP [25] }\end{array}$ & Oti River & $\begin{array}{c}\text { Lisflood \& } \\
\text { Lisflood-FP }\end{array}$ \\
\hline $\begin{array}{c}\text { Abdessamed } \\
\text { and Abderrazak } \\
(2019)\end{array}$ & $\begin{array}{c}\text { One-directional } \\
\text { coupling }\end{array}$ & $\begin{array}{c}\text { Ain Sefra; hydrological modeling; } \\
\text { hydraulic modeling; floods; } \\
\text { HEC-HMS; HEC-RAS [26] }\end{array}$ & Ain Sefra & $\begin{array}{c}\text { HEC HMS and } \\
\text { HEC RAS }\end{array}$ \\
\hline $\begin{array}{c}\text { Fleischmann } \\
\text { et al., (2017) }\end{array}$ & $\begin{array}{c}\text { One-directional } \\
\text { coupling }\end{array}$ & $\begin{array}{c}\text { Hlood regulation; hydrologic and } \\
\text { hydrodynamic; flood wave } \\
\text { attenuation; MGB-IPH 1 [27] }\end{array}$ & Upper Niger & $\begin{array}{c}\text { MGB-IPH- } \\
\text { hydrologic } \\
\text { and hydraulic } \\
\text { model }\end{array}$ \\
\hline $\begin{array}{c}\text { Fleischmann } \\
\text { et al., (2018) }\end{array}$ & $\begin{array}{c}\text { Two-directional } \\
\text { coupling }\end{array}$ & $\begin{array}{c}\text { Niger River Basin; Niger Inner } \\
\text { Delta; two-way coupling; } \\
\text { floodplain_hydrodynamics; } \\
\text { floodplain infiltration; semi-arid } \\
\text { wetlands [24] }\end{array}$ & $\begin{array}{c}\text { Upper Niger } \\
\text { and hydraulic } \\
\text { model }\end{array}$ & $\begin{array}{c}\text { MGB-IPH- } \\
\text { hydrologic }\end{array}$ \\
\hline
\end{tabular}

\subsection{The Coupled Modelling}

The use of coupled modelling in floodplain assessments was mostly performed in four (4) studies (Table 1). Three (3) [25-27] of the case studies were based on one-directional coupling of hydrology and hydraulic models, where the hydrology provides the boundaries for the hydraulic model in an offline manner. Ref. [25] focused on developing flood modelling approach to simulate flood extent in data scarce regions of Oti River basin, which is a sub-basin of the Volta River basin of West Africa based on a coupled model of a calibrated, distributed hydrological model for the whole basin to simulate the input discharges for a hydraulic model, which is used to predict the flood extent for a $140 \mathrm{~km}$ reach of the Oti River. The results demonstrated that with the use of remotely sensed datasets, a good hydrological model calibration (Nash Sutcliffe coefficient: 0.87) and validation (Nash Sutcliffe coefficient: 0.94) was possible. Furthermore, it was evident that even with coarse scale $(5 \mathrm{~km})$ input data, it was possible to simulate the discharge along this region's rivers, and importantly with a distributed model to derive model flows at any ungauged location within basin. While with a lack of surveyed channel bathymetry, which posed as a limitation, modelling the flood was only possible with the use subgrid hydraulic model. Flood models were able to fit the results relative to the observed 2007 flood extent and an extensive sensitivity testing showed that the fit $(64 \%)$ was likely to be as good as is possible for this region, given the coarseness of the terrain digital elevation model that was used. [26] investigated the inundation behavior of Ain Sefra river in Algeria during extreme flood events. In this paper, the methodological approach adopted, focused on the hydrologic modeling using the Hydrologic Engineering Center's hydrologic modeling system and the hydraulic modeling implemented in the Hydrologic Engineering Center's river analysis system. The approach had a combination of watershed modeling system model and geographic information system. In this case study, three types 
of simulation were performed with the flood return periods of 10,100 , and 1000 years. The hydraulic modeling simulations highlighted that the region most affected by the flood is the downtown area and the use of hydrologic and hydraulic modeling improved the simulation results of the flood area extent. The results obtained were very satisfactory. They researchers argued that the methodology of coupling of hydrological and hydraulic models can be adapted for the use of other catchment area of arid zones as it can form an important tool for the management of flood control and for real-time simulation of inundation. [27] demonstrated the application of MGB-IPH large scale one directional hydrologic and hydrodynamic model for the Upper Niger Basin. Model results showed a fair prediction for calibrated daily discharge and validated water level and altimetry at stations both upstream and downstream of the delta (Nash-Sutcliffe efficiency $>0.7$ for all stations), as well as for flooded areas within the delta region (ENS $=0.5 ; \mathrm{r} 2=0.8$ ), allowing a good representation of flooding dynamics.

However, although offline model coupling may be required to simulate natural or anthropic influences over wetland inflows, this method (one-directional coupling) is limited for not allowing two-way feedbacks between floodplain hydrodynamics and vertical hydrology (i.e., soil infiltration, evapotranspiration, etc.), since runoff generation and channel/floodplain dynamics are treated as independent processes [24]. Thus, study [24] extended coupling to a two-directional coupling scheme to obtain a closed feedback loop between hydrologic and hydrodynamic processes. In this case, exchange feedback processes were captured in the coupled model. Evaluation of model structure indicated that representation of both floodplain channels hydrodynamics (storage, bifurcations, lateral connections) and vertical hydrological processes (floodplain water infiltration into soil column; evapotranspiration from soil and vegetation and evaporation of open water) are necessary to correctly simulate flood wave attenuation and evapotranspiration along the basin. Such coupled hydrologic and hydraulic models prove to be an important tool for integrated evaluation of hydrological processes in large scale floodplain and data scarce areas.

\subsection{Coupled Models for Floodplain Management: Opportunities and Challenges}

Ref. [28] argue that discharge is a fundamental floodplain management variable, as well as being the primary input to the hydraulic model. All the reviewed case studies agree that discharge in floodplain processes was important in understanding the behavior of flood dynamics in floodplain. Ref. [29] reasons that proper estimation and management of flood characteristics and dynamics play a significant role in environmental assessments and the protection of floodplains. However, in Africa, understanding of flood magnitude estimation and management has not yet reached advanced stage yet either due to scarcity of data, especially in large basin that are poor gauged, or due to a lack of technological knowledge and tools for this kind of assessments. Thus, Africa can benefit from continued advances in accessibility of global remotely sensed datasets, open source hydrologic and hydraulic models for large basin and free versatile coupling framework that have been developed leading to improved and accurate assessment of floodplains for sustainable development. For example, as [30] states, openly available computational framework such as GLOFRIM makes a valuable contribution to current inundation modelling on the large scale by enhancing the integration of hydrological and hydrodynamic model processes, which eventually may lead to improved decision-making and planning of adaption and mitigation measures for sound floodplain management. Ref. [31] emphasis that detailed understanding of the hydrological and hydraulic characteristics of wetland hydrology is essential in order to develop sustainable ecological and hydrological management plans. The ecological status of the floodplain may be threatened by the increasing development of upstream catchments, as this affects the amount and timing of water delivered to the floodplain. Hydrological and hydraulic modelling of the floodplain wetland can form a basis of ecological studies and assessments in floodplains [28,32,33]. 
In Africa, among some of the limitations for developing effective coupled models is the lack of reliable and up-to-date in-situ data in many regions of the continent. Fortunately, opportunities exist for using remotely sensed datasets. This has led to increased use of satellite and reanalysis precipitation datasets in hydrological modelling [34]. Precipitation, for example, is one of the key drivers of watershed models. Currently there are many open-access precipitation datasets at different spatial and temporal resolutions over global or quasi-global scale [35]. Some commonly used open-access precipitation datasets in Africa include CHIRPS (Climate Hazards Group InfraRed Precipitation with Station data), TRMM (Tropical Rainfall Measuring Mission) and CFSR (Climate Forecast System Reanalysis) [36]. For example, Tropical Rainfall Measuring Mission (TRMM) satellite monthly rainfall product 3B43 and the Global Precipitation Climatology Centre full-reanalysis gridded precipitation dataset have proved to be useful for precipitation monitoring in regions, such as areas of central Africa, for which station data are difficult to obtain or in which there is poor station coverage [37]. Moreover, TRMM precipitation products have been extensively validated at ground sites around the world, some of these in Africa. [38] showed that TRMM estimations are in excellent agreement with gauge data over West Africa on monthly to seasonal time scales, with a root-mean-square (RMS) error of around $1 \mathrm{~mm}$ day 21 at monthly resolution [35]. It is also worth noting that the CHIRPS (Climate Hazards Group InfraRed Precipitation with Station data) precipitation dataset released in 2015 [39] provides daily precipitation at the finest spatial resolution of $0.05^{\circ}$ (one grid representing around $25 \mathrm{~km}^{2}$ ) from 1981 to present day. This high spatial resolution enables it to better define the spatial variability of precipitation and favors its application in hydrological studies at wider scales, including the lesser basins [36].

Modelling in hydrology typically involves the investigation of landscape and hydrological features such as terrain slope, drainage networks, and watershed boundaries. Traditionally, these features were determined from topographic maps, field surveys and sometimes photographic processing and interpretation. These traditional techniques are tedious, time consuming and prone to errors. GIS technology is being used exhaustively to overcome the challenges in spatially and temporally varying data to successfully model different hydrologic phenomena for different watersheds [40]. Digital Elevation Models (DEMs), including Advanced Spaceborne Thermal Emission and Reflection Radiometer-Global Digital Elevation Model (ASTER GDEM), Shuttle Radar Topography Mission (SRTM), and Global Multi-resolution Terrain Elevation Data 2010 (GMTED2010) are freely available for nearly the entire earth's surface [41]. Open-access global Digital Elevation Models (DEM) have been crucial in enabling flood studies in data-sparse areas such as on the continent of Africa. For example, in a study conducted in the Densu River Basin in Ghana applied the globally freely available DEMs; Advanced Spaceborne Thermal Emission and Reflection (ASTER) $30 \mathrm{~m}$ DEM and SRTM $90 \mathrm{~m}$ in their study of Densu River Basin. The results indicated that both DEMs have a good representation of the watershed of the Densu River Basin. The coarser resolution, SRTM, produce a better closeness in terms of watershed area and representation compared to the ASTER. For sensitivity modelling, such as flood forecasting, on the contrary, ASTER is apparently better as a result of high accuracy in the estimation of the longest flow length of the river. Particularly if considering the challenges for Africa that arise due to climate change and intensifying rainfall variabilities, remotely sensed products datasets discussed above can provide valuable up to date information beneficial for developing coupled hydrologic and hydraulic models [42].

Climate change and variability is having significant impacts on the freshwater ecosystems and the frequency and severity of flooding, with major implications for society and aquatic ecosystems such as floodplains [43]. On the continental level, there have been several climate impact studies focusing on water resources in Africa. In a study, Ref. [44] modelled the whole African continent with the SWAT (Soil and Water Assessment Tool) model. The authors compared the effects of climate change on streamflow results to the available literature sources on future projections of streamflow in Africa and several projections for smaller regions. They generally found similar trends in the studies, with decreases 
in the Sahel region and southern Africa between $10 \%$ and $20 \%$ and an increase in central and eastern Africa between $10 \%$ and $20 \%$, but with significant spatial variability. The sign and magnitude of future streamflow changes in studies conducted on the African continent vary between climate simulations and river basins, highlighting the uncertainties in the hydrologic projections on the continent. For example, overall in Ethiopia, the streamflow projections indicate large (seasonal, long-term mean and extreme) streamflow decreases for all major rivers in Ethiopia and increases in the equatorial parts of the region at the end of the century [45]. Therefore, in order to have a better understanding of present and future impact of climate change and variability on stream flow, coupled models for floodplain assessments need to be verified for their credibility of simulating extreme flows [46].

\subsection{Model Validation in Africa: Challenges and Opportunities}

Water resources managers are facing challenges in many river basins across the world due to limited data availability [47]. A particular problem in relation to validation of hydrological models in Africa is that, spatial data are seldom available for calibration and validation models. Therefore, models are mainly calibrated and validated against discharge data, which is fundamentally limits the documented performances of such models [48]. Specifically, in Africa discharge data are needed to validate both hydrological and hydraulic model simulations or as inputs to hydraulic models. Unfortunately, many rivers in Africa are not gauged, and where rivers are gauged, data are generally of poor quality (i.e., short periods and contain outliers), and in some cases, are affected by upstream water resource developments [49]. Moreover, many gauging stations in the wetlands are based on rated natural river sections rather than flow gauging structures which increases the possibility that channel hydraulic characteristics might change over time due to scouring or sedimentation especially in floodplains [50,51]. This, therefore, necessitates frequent updating of the stage-discharge rating curves. However, most of the stage-discharge rating curves are not updated frequently due to lack of resources and the remoteness of the gauge stations, and this inevitably introduces uncertainty in validation of model simulation results [52,53]. Nevertheless, the data-scarce nature of river basins in Africa due to the absence of ground-based observation data has been addressed using earth observation (EO) data which also help with model validation. The use of EO data coupled with a GIS has made substantial contributions to wetland studies $[54,55]$. Remote sensing products of different spatial resolutions and temporal coverage such as Landsat, SPOT (Satellite Pour l'Observation de la Terre), NOAA-AVHRR (Advanced Very High Resolution Radiometer), SAR (Synthetic Aperture Radar), LiDAR (Light Detection and Ranging), Radar systems, and TerraSAR-X are suitable for different wetland studies $[53,54]$.

Different studies $[12,55,56]$ have applied EO data to calibrate and/or validate models used to understand channel-wetland exchange processes and wetland dynamics. Ref. [57] used satellite images to establish river cross-sections, as well as to validate the calibrated model results in the Niger Inland Delta. Ref. [53] validated simulated inundation extents by comparing with the available Landsat level 1 images. Water pixels from the selected Landsat level 1 images were extracted using the Modified Normalised Difference Water Index (MNDWI) and the results were used to represent the observed inundation extents. The extracted water pixels together with the simulated inundated extents were used to calculate the Flood Area Index (FAI) [58] in order to assess the model performance [53]. Another study [7] demonstrated the linkage between discharge and inundation extent overtime in the Barotse floodplain by using optical satellite imagery MODIS. The Desert Flood Index, a surface water extraction algorithm, was used to generate time series of inundation extent. For validation of the inundation extent, they used a flood mask extracted from a supervised classification land cover map using Landsat imagery. The land cover map was validated using the error matrix method with ground truth data. The estimated inundation extent time series enabled them to test the inundation correlation with discharge and water level using Pearson r correlation, a parametric statistical test. Based on the established correlation they used the Mann-Kendall, a non-parametric test, to analyse trends in the 
inundation extent and discharge and water level time series from which we made inferences on the direction of the historical trend in inundation extent. Meanwhile, Ref. [59] conducted a study in Ogun River Basin, Nigeria, and the main objective of this study was to calibrate and validate the eco-hydrological model Soil and Water Assessment Tool (SWAT) with satellite-based evapotranspiration (ET) data from the Moderate Resolution Imaging Spectroradiometer Global Evaporation (MOD16). Especially for the fact that evapotranspiration (ET) is the second most important element in hydrological modelling after precipitation as it facilitates the continuation of precipitation by replacing the vapor lost through condensation, hence very important for hydrological modelling. The stud [59] demonstrated the potential use of remotely sensed evapotranspiration data for hydrological model calibration and validation in a sparsely gauged large river basin with reasonable accuracy. The results from this research contributed to a better understanding of the ease and suitability of using freely available satellite-based ET datasets for model calibration in tropical ungauged basins where the main limitation of setting up hydrological models for discharge simulations is the lack of calibration and validation data. In addition to the evaporation products from MOD16, the European Organization for the Exploitation of Meteorological Satellites Meteosat Second Generation (EUMETSAT MSG) ET product is also available. However, MOD16 ET product has a finer spatial resolution of $1 \mathrm{~km}$ and a temporal resolution of 8 days, monthly and yearly ET. The EU-METSAT MSG ET product is available at $3 \mathrm{~km}$ spatial resolution every $30 \mathrm{~min}$ or daily. However, these products have been calibrated and validated mainly in the Northern hemisphere, with sites located in North and South America, Europe and Asia [60]. Hence, there is a need for more studies to evaluate global remote sensing ET products at long term monitoring sites in Africa [60]. It is kind of application of remotely based products and techniques as discussed that can be utilised to overcome challenges and limitations associated with validating hydrologic and hydraulic coupled models results in data scarce river basins in Africa.

\section{Conclusions}

Case studies reviewed in this paper have pointed towards the potential use of coupled hydrologic - hydraulic models and the opportunities present to be used in Africa especially for data scarce and large basin for floodplain assessments. Model coupling is necessary to better understand hydrological processes in floodplain wetlands especially the twodirectional model coupling. Coupled hydrologic and hydrodynamic modelling has proven to be an important tool for integrated evaluation of hydrological processes in poorly gauged, large scale basins. Representation of both floodplain channels hydrodynamics (storage, bifurcations, lateral connections) and vertical hydrological processes (floodplain water infiltration into soil column; evapotranspiration from soil and vegetation and evaporation of open water) in coupled models are necessary to correctly simulate flood wave attenuation and evapotranspiration in floodplain modelling. Many wetlands in Africa are currently under pressure due to building of reservoirs, irrigation schemes, land use and cover changes, climate change, and variability. To give their environmental value, it is thus fundamental to apply coupled models in floodplains assessments, in order to advance knowledge of their main hydrological processes, where both modelling techniques and remote sensing-based methods may be useful. In Africa it is necessary to understand the flood dynamics of these complex systems (floodplains) to improve prediction capabilities of the floodplain wetlands response under current and future alterations. The availability of open access models, coupling frameworks, and remotely sensed datasets as presented in this paper, offer timely opportunities for application of coupled models in data scarce basins on the continent of Africa, for improved hydrological assessment in floodplains, especially with the advent of climate change and climate variability experienced across the continent.

Funding: This work was funded by Worldwide Fund for Nature (WWF) Zambia, grant number 40001528 under Upper Zambezi Programme through the Wetland Assessment and Ecosystem 
Services Project (WASP) at The University of Zambia, Integrated Water Resources Management (IWRM)-Centre hosted in the Geology Department, School of Mines.

Institutional Review Board Statement: Not applicable.

Informed Consent Statement: Not applicable.

Data Availability Statement: The information on data presented in this study are available on request from the corresponding author.

Acknowledgments: We are grateful to the Worldwide Fund for Nature (WWF) Zambia and IWRM Center coordinators for supporting this work. Thanks are also due to the anonymous reviewers for their comprehensive review of the paper and for their many helpful suggestions. We strongly feel that the manuscript has been greatly improved as a result of their thoughtful insight.

Conflicts of Interest: The authors declare no conflict of interest.

\section{References}

1. Button and Tiner. Ecology of Wetlands; Button and Tiner: Wetlands, Germany, 2009; pp. 507-515.

2. SANBI. What Is a Wetland? Wetland-Use Booklet 2. South African National Biodiversity Institute, 2016. Available online: http:/ /biodiversityadvisor.sanbi.org/wp-content/uploads/2016/07/What-is-a-wetland.pdf (accessed on 4 April 2020).

3. Mitsch, W.; Gosselink, J. Wetlands, 3rd ed.; John Wiley \& Sons: New York, NY, USA, 2000.

4. Tiner, R.W. Ecology of Wetlands: Classification Systems; Elsevier: Wetlands, Germany, 2009; pp. 516-525.

5. Meitzen, K.M. Floodplains. In Reference Module in Earth Systems and Environmental Sciences; Elsevier: Amsterdam, The Netherlands, 2018; pp. 2-6.

6. Lockaby, B.G.; Conner, W.H.; Mitchell, J. Floodplains. In Ecosystem Ecology; Elsevier: Oxford, UK, 2009 ; pp. $253-266$.

7. Zimba, H.; Kawawa, B.; Chabala, A.; Phiri, W.; Selsam, P.; Meinhardt, M.; Nyambe, I. Assessment of trends in inundation extent in the Barotse Floodplain, upper Zambezi River Basin: A remote sensing-based approach. J. Hydrol. Reg. Stud. 2018, 15, 149-170. [CrossRef]

8. Papas, P. Index of Wetland Condition Conceptual Framework and Selection of Measures; Technical Report; Victorian Government Department of Sustainability and Environment Melbourne: Melbourne, Australia, 2005.

9. Phiri, W.K.; Vanzo, D.; Banda, K.; Nyirenda, E.; Nyambe, I.A. A pseudo-reservoir concept in SWAT model for the simulation of an alluvial floodplain in a complex tropical river system. J. Hydrol. Reg. Stud. 2021, 33, 100770. [CrossRef]

10. Zhang, G.H. Potential effects of climate change on rainfall erosivity in the Yellow River basin of China. Trans. ASAE 2005, 48, 511-517. [CrossRef]

11. Zhang, X.; Srinivasan, R.; Hao, F. Predicting Hydrologic response to Climate Change in the Luohe River Basin Using the SWAT model. American Society of Agricultural and Biological Engineers. Trans. ASABE 2007, 50, 901-910. [CrossRef]

12. Schumann, G.J.P.; Neal, J.C.; Voisin, N.; Andreadis, K.M.; Pappenberger, F.; Phanthuwongpakdee, N.; Hall, A.C.; Bates, P.D. A first large-scale flood inundation forecasting model. Water Resour. Res. 2013, 49, 6248-6257. [CrossRef]

13. Hunter, N.M.; Bates, P.D.; Horritt, M.S.; Wilson, M.D. Simple Spatially distributed models for predicting flood inundation: A review. Geomorphology 2007, 90, 208-225. [CrossRef]

14. Hoch, J.M.; Neal, J.C.; Baart, F.; van Beek, R.; Winsemius, H.C.; Bates, P.D.; Bierkens, M.F.P. GLOFRIM v1.0—A globally applicable computational framework for integrated hydrological-hydrodynamic modelling. Geosci. Model Dev. 2017, 10, 3913-3929. [CrossRef]

15. Singh, V.P.; Asce, F.; Woolhiser, D.A. Mathematical Modelling of Watershed Hydrology. J. Hydrol. Eng. 2002, 7, 270-291. [CrossRef]

16. Abshire, K.E. Impacts of Hydrologic and Hydraulic Model Connection Schemes on Flood Simulation and Inundation Mapping in the Tar River Basin. Master's Thesis, Duke University, Durham, NC, USA, 2012.

17. Wang, Y.; Yang, X. A Coupled Hydrologic-Hydraulic Model (XAJ-HiPIMS) for Flood Simulation. Water 2020, 12, 1288. [CrossRef]

18. Betrie, G.D.; van Griensven, A.; Mohamed, Y.A.; Popescu, I.; Mynett, A.E.; Hummel, S. Linking SWAT and SOBEK using Open Modeling Interface (OpenMI) for sediment transport simulation in the Blue Nile River basin. Trans. ASABE 2011, 54, $1749-1757$. [CrossRef]

19. Haghizadeh, A.; Shui, L.T.; Mirzaei, M.; Memarian, H. Incorporation of GIS Based Program into Hydraulic Model for Water Level Modeling on River Basin. J. Water Resour. Prot. 2012, 4, 25-31. [CrossRef]

20. Hoch, J.M.; Eilander, D.; Ikeuci, H.; Baart, F.; Winsemius, H.C. Evaluating the impact of model complexity on flood wave propagation and inundation extent with a hydrologic-hydrodynamic model coupling framework. Nat. Hazards Earth Syst. Sci. 2019, 19, 1723-1735. [CrossRef]

21. Lian, Y.; Chan, I.-C.; Singh, J.; Demissie, M.; Knapp, V.; Xie, H. Coupling of hydrologic and hydraulic models for the Illinois River Basin. J. Hydrol. 2007, 344, 210-222. [CrossRef]

22. Biancamaria, S.; Bates, P.D.; Boone, A.; Mognard, N.M. Large-scale coupled hydrologic and hydraulic modelling of the Ob river in Siberia. J. Hydrol. 2009, 379, 136-150. [CrossRef] 
23. CEE (Collaboration for Environmental Evidence). Guidelines for Systematic Review and Evidence Synthesis in Environmental Management. Version 4.2. Environmental Evidence. 2013. Available online: www.environmentalevidence.org/Documents/ Guidelines/Guidelines4.2.pdf (accessed on 5 May 2020).

24. Fleischmann, A.; Siqueira, V.; Paris, A.; Collischonn, W.; Paiva, R.; Pontes, P.; Crétaux, J.F.; Bergé-Nguyen, M.; Biancamaria, S.; Gosset, M.; et al. Modelling hydrologic and hydrodynamic processes in basins with large semi-arid wetlands. J. Hydrol. 2018, 561, 943-959. [CrossRef]

25. Komi, K.; Neal, J.; Trigg, M.A.; Diekkrüger, B. Modelling of flood hazard extent in data sparse areas: A case study of the Oti River basin, West Africa. J. Hydrol. Reg. Stud. 2017, 10, 122-132. [CrossRef]

26. Abdessamed, D.; Abderrazak, B. Coupling HEC-RAS and HEC-HMS in rainfall-runoff modeling and evaluating floodplain inundation maps in arid environments: Case study of Ain Sefra city, Ksour Mountain. SW of Algeria. Environ. Earth Sci. 2019, 78, 1-17. [CrossRef]

27. Fleischmann, A.; Siqueira, V.; Paris, A.; Collischonn, W.; Paiva, R.; Gossett, M.; Pontes, P.; Calmant, S.; Biancamaria, S.; Crétaux, J.F.; et al. Coupled hydrologic and hydraulic modeling of Upper Niger River Basin. Geophys. Res. Abstr. 2017, $19,884$.

28. Birkhead, A.L.; James, C.S.; Kleynhans, M.T. Hydrological and hydraulic modelling of the Nyl River floodplain Part 2: Modelling hydraulic behaviour. Water SA 2007, 33, 9-20. [CrossRef]

29. Feyissaa, T.A.; Tufa, F.G. Floodplain Modelling of Awetu River Sub-Basin, Jimma, Oromia, Ethiopia. J. Mater. Environ. Sci. 2019, 10, 1030-1042.

30. Hoch, J.M.; Arjen, V.; Haag, A.V.; van Dam, A.; Winsemius, H.C.; Ludovicus, P.H.; van Beek, L.P.H.; Bierkens, M.F.P. Assessing the impact of hydrodynamics on large scale flood wave propagation-A case study for the Amazon Basin. Hydrol. Earth Syst. Sci. 2017, 21, 117-132. [CrossRef]

31. Rowberry, M.D.; McCarthy, T.S.; Thompson, M.; Nomnganga, A.; Moyo, L. The spatial and temporal characterisation of flooding within the floodplain wetland of the Nyl River, Limpopo Province, South Africa. Water SA 2011, 37, 445-452. [CrossRef]

32. Havenga, C.F.B.; Pitman, W.V.; Bailey, A.K. Hydrological and hydraulic modelling of the Nyl River floodplain, Part 1 Background and hydrological modelling. Water SA 2007, 33, 1-8. [CrossRef]

33. Clilverd, H.M.; Thompson, J.R.; Heppell, C.M.; Sayer, C.D.; Axmacher, J.C. Coupled Hydrological/Hydraulic Modelling of River Restoration Impacts and Floodplain Hydrodynamics. River Res. Appl. 2016, 32, 1927-1948. [CrossRef]

34. Kleynhans, M.T.; James, C.S.; Birkhead, A.L. Hydrologic and hydraulic modelling of the Nyl River floodplain, Part 3: Applications to assess ecological impact. Water SA 2007, 33, 21-26. [CrossRef]

35. Poméon, T.; Jackisch, D.; Diekkrüger, B. Evaluating the performance of remotely sensed and reanalysed precipitation data over West Africa using HBV light. J. Hydrol. 2017, 547, 222-235. [CrossRef]

36. Naumann, G.; Barbosa, P.; Carrao, H.; Singleton, A.; Vogt, J. Monitoring Drought Conditions and Their Uncertainties in Africa Using TRMM Data. J. Appl. Meteorol. Climatol. 2012, 51, 1867-1874. [CrossRef]

37. Duan, Z.; Tuo, Y.; Liu, J.; Gao, H.; Song, X.; Zhang, Z.; Mekonnen, D.F. Hydrological evaluation of open-access precipitation and air temperature datasets using SWAT in a poorly gauged basin in Ethiopia. J. Hydrol. 2019, 569, 612-626. [CrossRef]

38. Jenkins, G.S. TRMM satellite estimates of convective processes in central Africa during September, October, November 1998: Implications for elevated Atlantic tropospheric ozone. Geophys. Res. Lett. 2000, 27, 1711-1714. [CrossRef]

39. Nicholson, S.E.; Some, B.; Mccollum, J.; Nelkin, E.; Klotter, D.; Berte, Y.; Diallo, B.M.; Gaye, I.; Kpabeba, G.; Ndiaye, O.; et al. Validation of TRMM and Other Rainfall Estimates with a High-Density Gauge Dataset for West Africa. Part II: Validation of TRMM Rainfall Products. J. Appl. Meteorol. 2003, 42, 1355-1368. [CrossRef]

40. Funk, C.; Peterson, P.; Landsfeld, M.; Pedreros, D.; Verdin, J.; Shukla, S.; Husak, G.; Rowland, J.; Harrison, L.; Hoell, A.; et al. The climate hazards infrared precipitation with stations-A new environmental record for monitoring extremes. Sci. Data 2015, 2, 150066. [CrossRef]

41. Anornu, G.K.; Kabo-bah, A.; Kortatsi, B.K. Comparability Studies of High and Low Resolution Digital Elevation Models for Watershed Delineation in the Tropics: Case of Densu River Basin of Ghana. Int. J. Coop. Stud. 2012, 1, 9-14.

42. Athmania, D.; Achour, H. External Validation of the ASTER GDEM2, GMTED2010 and CGIAR-CSI- SRTM v4.1 Free Access Digital Elevation Models (DEMs) in Tunisia and Algeria. Remote Sens. 2014, 6, 4600-4620. [CrossRef]

43. Falloon, P.D.; Betts, R.A. The impact of climate change on global river flow in HadGEM1 simulations. Atmos. Sci. Lett. 2016, 7, 62-68. [CrossRef]

44. Faramarzi, M.; Abbaspour, K.C.; Vaghefi, S.A.; Farzaneh, M.R.; Zehnder, A.J.B.; Srinivasan, R.; Yang, H. Modeling impacts of climate change on freshwater availability in Africa. J. Hydrol. 2013, 480, 85-101. [CrossRef]

45. Feyera, A.H.; Lorenzo, A.; Lees, T.; Peng, J.; Dyer, E.; Dadson, S.J. Streamflow response to climate change in the Greater Horn of Africa. Clim. Chang. 2019, 156, 341-363.

46. Taye, M.T.; Ntegeka, V.; Ogiramoi, N.P.; Willems, P. Assessment of climate change impact on hydrological extremes in two source regions of the Nile River Basin. Hydrol. Earth Syst. Sci. 2011, 15, 209-222. [CrossRef]

47. Begou, J.C.; Jomaa, S.; Benabdallah, S.; Bazie, P.; Afouda, A.; Rode, M. Multi-Site Validation of the SWAT Model on the Bani Catchment: Model Performance and Predictive Uncertainty. Water 2016, 8, 178. [CrossRef]

48. Andersen, J.; Refsgaard, J.C.; Jensen, K.H. Distributed hydrological modelling of the Senegal River Basin-Model construction and validation. J. Hydrol. 2001, 247, 200-214. [CrossRef] 
49. Hughes, D.A.; Kapangaziwiri, E.; Sawunyama, T. Hydrological model uncertainty assessment in southern Africa. J. Hydrol. 2010, 387, 221-232. [CrossRef]

50. Di Baldassarre, G.; Montanari, A. Uncertainty in river discharge observations: A quantitative analysis. Hydrol. Earth Syst. Sci. 2009, 13, 913-921. [CrossRef]

51. Westerberg, I.; Guerrero, J.L.; Seibert, J.; Beven, K.J.; Halldin, S. Stage-discharge uncertainty derived with a non-stationary rating curve in the Choluteca River, Honduras. Hydrol. Process. 2011, 25, 603-613. [CrossRef]

52. Coxon, G.; Freer, I.K.W.; Wagener, T.; Woods, R.; Smith, P.J. A novel framework for discharge uncertainty quantification applied to 500 UK gauging stations. Water Resour. Res. 2015, 51, 5531-5546. [CrossRef]

53. Makungu, E. A Combined Modelling Approach for Simulating Channel-Wetland Exchanges in Large African River Basins. Ph.D. Thesis, Rhodes University, Grahamstown, South Africa, 2019.

54. Mwita, E.; Menz, G.; Misana, S.; Becker, M.; Kisanga, D.; Boehme, B. Mapping small wetlands of Kenya and Tanzania using remote sensing techniques. Int. J. Appl. Earth Obs. Geo-Inf. 2013, 21, 173-183. [CrossRef]

55. Heimhuber, V.; Tulbure, M.G.; Broich, M. Modeling 25 years of spatio-temporal surface water and inundation dynamics on large river basin scale using time series of Earth observation data. Hydrol. Earth Syst. 2016, 20, 2227-2250. [CrossRef]

56. Trigg, M.A.; Michaelides, K.; Neal, J.C.; Bates, P.D. Surface water connectivity dynamics of a large scale extreme flood. J. Hydrol. 2013, 505, 138-149. [CrossRef]

57. Neal, J.; Schumann, G.; Bates, P. A subgrid channel model for simulating river hydraulics and floodplain inundation over large and data sparse areas. Water Resour. Res. 2012, 48, 1-16. [CrossRef]

58. Fernández, A.; Reza, M.; Durand, M.; Mark, B.; Moritz, M.; Chul, H.; Neal, J.; Shastry, A.; Laborde, S.; Chian, S.; et al. Testing the skill of numerical hydraulic modeling to simulate spatiotemporal flooding patterns in the Logone floodplain, Cameroon. $J$. Hydrol. 2016, 539, 265-280. [CrossRef]

59. Odusanya, A.E.; Mehdi, B.; Schürz, C.; Oke, A.O.; Olufiropo, S.; Awokola, O.S.; Awomeso, J.A.; Adejuwon, J.O.; Schulz, K. Multi-site calibration and validation of SWAT with satellite-based evapotranspiration in a data-sparse catchment in southwestern Nigeria. Hydrol. Earth Syst. Sci. 2019, 23, 1113-1144. [CrossRef]

60. Ramoelo, A.; Majozi, N.; Mathieu, R.; Jovanovic, N.; Nickless, A.; Dzikiti, S. Validation of Global Evapotranspiration Product (MOD16) using Flux Tower Data in the African Savanna, South Africa. Remote Sens. 2014, 6, 7406-7423. [CrossRef] 